\title{
Apparent ileal amino acid digestibility and energy utilization in hulless oats (Avena nuda L) fed to growing pigs*
}

\author{
C.M. Nyachoti ${ }^{1}$, L. Rigaux, T.A. Woyengo and E. Kiarie
}

\author{
Department of Animal Science, University of Manitoba \\ Winnipeg, Manitoba, Canada, R3T 2N2
}

(Received 9 April 2009; revised version 27 October 2009; accepted 29 January 2010)

\begin{abstract}
The aim of the present work was to determine nutrients and energy utilization of four hulless oat varieties, namely Paul (PA), Gehl "VAO-02" (GV), AC-Gwen (AC) and Lee Williams (LW) in growing pigs. The crude protein, lysine, crude fat and neutral detergent fibre contents $\left(\mathrm{g} \mathrm{kg}^{-1} \mathrm{DM}\right)$ ranged from 153 for LW to 184 for PA, 7.08 for $\mathrm{LW}$ to 7.94 for PA, 53.8 for $\mathrm{LW}$ to 72.1 for $\mathrm{GV}$ and 77.3 for PA to 120 for LW, respectively. Apparent ileal lysine digestibility differed $(\mathrm{P}<0.05)$ among the varieties and ranged from $60.0 \%$ for $\mathrm{LW}$ to $78.9 \%$ for $\mathrm{AC}$. The $\mathrm{DE}$ and $\mathrm{ME}$ contents $\left(\mathrm{MJ} \mathrm{kg}^{-1}\right)$ also differed $(\mathrm{P}<0.05)$ among the varieties and ranged from 16.66 for $\mathrm{LW}$ to 17.92 for $\mathrm{PA}$ and 16.65 for LW to 17.90 for PA, respectively.

Ileal amino acids digestibility and energy contents revealed variability among the varieties studied.
\end{abstract}

KEYWORDS: hulless oats, amino acid digestibility, energy, pigs

\section{INTRODUCTION}

In the recent past, the global feed industry has seen soaring prices of cereal grains commonly used in livestock diets as the competition with the ethanol industry increases. This trend has clearly demonstrated the danger of relying

\footnotetext{
* Presented in part at the Canadian Society for Animal Science Meeting at the University of Guelph, Guelph, Ontario, Canada, August 11-14, 2008

${ }^{1}$ Corresponding author: e-mail: martin_nyachoti@umanitoba.ca
} 
on a limited pool of ingredients to formulate pig diets and underscored the need to characterize the nutritive value of other feedstuffs with potential to serve as alternatives to traditional feedstuffs in pig diets.

Conventional oats (Avena sativa $\mathrm{L}$.) are not commonly used in pig diets mainly due to high fibre content. Thus, there has been increased interest in developing oats with reduced fibre content that may be used in large amounts in diets for nonruminant animals. The relentless efforts in plant genetics and improvement research have led to the development of hulless oat varieties with much lower fibre than conventional oats (Morris, 1990). The reasoning for this is based on the known fact that high dietary fibre not only reduces feed intake in pigs but also has anti-nutritional effects that reduce effective energy and nutrient utilization (Nyachoti et al., 1997). In addition to the lower fibre content, hulless oats have a higher content of fat, crude protein (CP) and amino acids (AA) compared to hulled oat and other cereals (Morris, 1990). Because of its high CP, it has been suggested that hulless oat could replace considerable proportion of traditional protein sources in pig diets (Van Barneveld et al., 1998). The utilization of varieties of hulless oats that contain higher oil could provide an alternative method of increasing the energy density of pig diets and as well produce diets that are less dusty compared to commonly used cereals (Mulcy et al., 2005). Energy- and nutrient-dense diets have the potential to improve feed efficiency, which could be economically beneficial to the pig industry. Indeed, studies with pigs (Givens et al., 2004; Thacker et al., 2004; Thacker, 2006) have shown that hulless oat has higher nutritive value compared with hulled oat varieties.

In a recent study with growing-finishing pigs, Thacker (2006) reported no differences in apparent total tract digestibility of dry matter, crude protein and energy in normal vs hulless oat and no differences in crude protein digestibility between hulless oat and barley. To optimize dietary protein and AA utilization in pig, ileal digestibility measurements should be used in dict formulation. Furthermore, the utilization of energy in hulless oats must be known to fully evaluate the significance of oil concentration and reduced fibre content. However, the apparent ileal digestibility of AA has only been determined in limited studies (e.g., Van Barneveld et al., 1998) and there is dearth of information on energy metabolizability in hulless oat. Therefore, the objectives of the current study were to 1 . characterize the chemical composition of four hulless oat varieties available in Western Canada and 2. to determine the digestibility of AA and metabolizable energy in four varieties of hulless oat fed to growing pigs. 


\section{MATERIAL AND METHODS}

\section{Hulless oats cultivars and experimental diets}

The four hulless oat varieties namely Paul (PA), AC-Gwen (AC), Gehl "VAO02" (GV) and Lee Williams (LW) were procured from a local Manitoba oats grower association (Winnipeg, MB, Canada). All samples were evaluated 'as received' apart from grinding in a Vicking hammer mill (Horvick Manufacturing, Fargo, ND, USA) through a 3-mm screen prior to mixing the experimental diets. The study used four diets containing $976 \mathrm{~g} \mathrm{~kg}^{-1}$ of one of each of the four oat samples as the sole source of energy and protein, and supplemented with vitamins and minerals to meet or exceed NRC (1998) recommendations (Table 1). Chromic oxide $\left(\mathrm{Cr}_{2} \mathrm{O}_{3} 3.0 \mathrm{~g} \mathrm{~kg}^{-1}\right)$ was included in all diets as an indigestible marker for determining energy and nutrient digestibilities. Diets were prepared in mash form.

Table 1. Composition of experimental diets, $\mathrm{g} \mathrm{kg}^{-1}$

\begin{tabular}{lc}
\hline Ingredient & Amount \\
\hline Hulless oat & 967 \\
Limestone & 10.5 \\
Monocalcium phosphate & 7.00 \\
lodized salt & 2.50 \\
Vitamin-mineral premix $^{2}$ & 10.0 \\
Chromic oxide & 3.00 \\
\hline
\end{tabular}

The four experimental diets were formulated by including one of each hulless oat variety as the sole source of energy and protein. The hulless oat varieties evaluated were: Paul (Diet 1), Gehl-VAO02 (Diet 2), AC Gwen (Diet 3), and Lee Williams (Diet 4); ${ }^{2}$ supplied the following per $\mathrm{kg}$ of diet, IU: vit. A 8255 , vit. D3 1000 , vit. E 20 , vit. K 1.5; $\mathrm{mg}$ : riboflavin 7.5 , niacin 30 , pyridoxine 4.5 , folic acid 1 , thiamin 4 , choline 781 , copper 10 , iodine 0.6 , iron 130 , manganese 40 , selenium 0.3 , zinc $130 ; \mu$ g: vit. $B_{12} 25$, biotin 200

\section{Animals and housing}

The study utilized four barrows obtained from the University of Manitoba Glenlea Pig Research Unit, with an average initial body weight $47.0 \pm 1.24 \mathrm{~kg}$. Pigs were individually housed in adjustable metabolism crates $(1.8 \times 0.6 \mathrm{~m})$ with smooth transparent plastic sides and plastic-covered expanded metal sheet flooring in a temperature-controlled room $\left(22 \pm 2^{\circ} \mathrm{C}\right)$. Pigs were allowed to adjust to the metabolism crates for $8 \mathrm{~d}$ before they were surgically fitted with a T-cannula at the distal ileum and cared for as described by Nyachoti et al. (2002).

The use of pigs and experimental procedures were reviewed and approved by the Animal Care Committee of the University of Manitoba. Animals were cared for according to the standard guidelines of the Canadian Council on Animal Care (CCAC, 1993). 


\section{Experimental design and procedures}

Experimental diets were assigned to the four pigs in a $4 \times 4$ Latin square design. Feed was supplied in a daily amount equal to $4 \%$ body weight at the beginning of every experimental period. The daily feed allotment was divided into two equal portions and offered at 08.00 and 16.00 . Feed refusal and spillage were recorded and used to determine actual dry matter intake. Pigs had unlimited access to drinking water from low pressure drinking nipples. During each experimental period, pigs were allowed to acclimatize to their respective experimental diets for $5 \mathrm{~d}$. Faeces and urine were then collected quantitatively over a 3-d period. Each metabolism crate had a collection tray for urine and a fine-mesh plastic net just above the tray for faecal collection. In addition, glass wool was placed in the funnel of the collection trays to trap any faeces not retained by the net. The sample collection procedures were similar to those described by Nyachoti et al. (2006). Urine was collected into plastic pails containing $50 \mathrm{ml}$ of $5 \% \mathrm{HCl}$. After measuring the daily volume, $100-\mathrm{ml}$ aliquots were taken for each 24 -h period and kept frozen until analysed. Faeces were weighed daily and stored at $-20^{\circ} \mathrm{C}$ until analysed. Ileal digesta was collected continuously for a 12-h period on $\mathrm{d} 9$ and 10 to determine apparent ileal AA digestibilitics. Digesta were collected into plastic bags that were attached to the barrel of the T-cannulas by a hose clamp. Collection bags contained $10 \mathrm{ml}$ of $10 \%$ ( $\mathrm{vol} / \mathrm{vol}$ ) formic acid to minimize bacterial activity. Every 1 to $2 \mathrm{~h}$, the collected digesta were removed and immediately frozen at $-20^{\circ} \mathrm{C}$ until processed.

\section{Sample preparation and chemical analyses}

Ileal digesta samples were pooled per pig per period by homogenizing the samples in a heavy duty blender (Waring Commercial, Torrington, CT, USA) and approximately $200 \mathrm{~g}$ digesta were sub-sampled for chemical analyses. Faecal and ileal samples were lyophilized and, along with oats and diet samples, finely ground in a CBG5 Smart Grind ${ }^{\mathrm{TM}}$ coffee grinder (Applica Consumer Products, Inc., Shelton, CT, USA) and thoroughly mixed before analyses. The oats were analysed for dry matter (DM), nitrogen $(\mathrm{N})$, crude fat $(\mathrm{CF})$, neutral detergent fibre (NDF), acid detergent fibre (ADF) and AA. Diet, faecal and digesta samples were analysed for gross energy (GE), DM, N and $\mathrm{Cr}_{2} \mathrm{O}_{3}$ contents. Digesta and diet samples were further analysed for AA content.

Dry matter was determined according to the method of the AOAC $(1990 ;$ method 925.09) and $\mathrm{N}$ was determined using a LECO CNS-2000 Elemental Analyzer (LECO Corp., St. Joseph, MI, USA). Oat samples were analysed for NDF and ADF according to Van Soest et al. (1991) using ANKOM ${ }^{200}$ Fibre Analyzer (ANKOM 
Technology, Macedon, NY, USA) and CF according to the AOAC (1990). Oat, diet and digesta samples were analysed for AA according to the AOAC (1990; method 982.30) procedure using a cation exchange column in an LKB 4151 Alpha plus AA Analyzer (LKB Biochrom, Cambridge, UK) equipped with an LKB 4029 programmer and a 3393A Hewlett-Packard Integrator (Hewlett-Packard Co., Avondale, PA). Briefly, $100 \mathrm{mg}$ of each sample was hydrolysed with $6 \mathrm{~mol} \mathrm{l}^{-1}$ $\mathrm{HCl}$ at $110^{\circ} \mathrm{C}$ for $24 \mathrm{~h}$. Cysteine and methionine were determined by oxidizing the sample with performic acid prior to acid hydrolysis. Tryptophan was not determined. Samples were analysed for GE using an automated adiabatic oxygen bomb calorimeter (Parr Instrument Co., Moline, IL, USA); benzoic acid was used as reference material. Samples for $\mathrm{Cr}_{2} \mathrm{O}_{3}$ concentrations were ashed and digested according to Williams et al. (1962) and read on a Varian inductively coupled plasma mass spectrometer (Varian Inc., Palo Alto, Mississauga, Canada).

\section{Calculations and statistical analysis}

Apparent ileal digestibilities were calculated using a marker method $\left(\mathrm{Cr}_{2} \mathrm{O}_{3}\right)$ using the following equation:

$\%$ apparent nutrient digestibility $=100-\left[\left(\mathrm{C}_{\text {diet }} / \mathrm{C}_{\text {digestat }} * \mathrm{~N}_{\text {digesta }} / \mathrm{N}_{\text {diet }}\right) * 100\right]$

where: $\mathrm{C}_{\text {diet }}-\mathrm{Cr}_{2} \mathrm{O}_{3}$ concentration in diet $(\%) ; \mathrm{C}_{\text {digesta }}-\mathrm{Cr}_{2} \mathrm{O}_{3}$ concentration in ileal digesta (\%); $\mathrm{N}_{\text {digesta }}$ - nutrient concentration ileal digesta (\%); $\mathrm{N}_{\text {diet }}$ - nutrient concentration in the diet $(\%)$.

Total tract nutrient digestibility and energy retention were determined by total collection method using the following equation:

Total tract nutrient digestibility $(\%)=100 \times\left[\left(\mathrm{NI}^{-\mathrm{NO}_{\text {faeces }}}\right) / \mathrm{NI}\right]$ and energy balance $(\%)=100 \times\left[\left(\mathrm{EI}^{-\mathrm{EO}_{\text {facces }}}-\mathrm{EO}_{\text {urine }}\right) / \mathrm{EI}\right]$,

where: NI - nutrient intake; $\mathrm{NO}_{\text {faces }}$ - nutrient output in faeces; $\mathrm{EI}$ - energy intake; $\mathrm{EO}_{\text {faeces }}$ - energy output in faeces; $\mathrm{EO}_{\text {urinc }}$ - energy output in urine.

Digestible (DE) and metabolizable (ME) energy contents of the diets were determined using the following equation:

$\mathrm{DE}$ or $\mathrm{ME}\left(\mathrm{MJ} \mathrm{kg}^{-1}\right)=[($ energy digestibility or retention in diet, $\%) \times($ gross energy content in diet)]/100.

The data were subjected to the mixed model procedures of SAS (SAS software release 9.1; SAS Institute, Cary, NC, USA). The model contained the fixed effects 
of the diet and the random effects of the pig and period. An alpha level of 0.05 was used for determination of statistical significance.

\section{RESULTS}

Chemical composition. The proximate analysis and GE contents of the hulless oat varieties tested is given in Table 2 . The CP content $\left(\mathrm{g} \mathrm{kg}^{-1} \mathrm{DM}\right)$ varied from a low of 153 for LW to 184 for PA with an overall average of 167 for all four

Table 2. Proximate analysis ( $\left.\mathrm{g} \mathrm{kg}^{-1} \mathrm{DM}\right)$ and gross energy ( $\mathrm{MJ} \mathrm{kg}^{-1} \mathrm{DM}$ basis) of hulless oat varicties

\begin{tabular}{lcccc}
\hline \multirow{2}{*}{ Item } & \multicolumn{4}{c}{ Hulless oat varieties } \\
\cline { 2 - 5 } & Paul & Gehl VAO-02 & AC Gwen & LeeWilliams \\
\hline Dry matter & 932 & 933 & 934 & 932 \\
Crude protein $(\mathrm{N} \times 6.25)$ & 184 & 171 & 161 & 153 \\
Crude fat (hexane extracts) & 68.2 & 72.1 & 64.2 & 53.8 \\
& & & & \\
Fibre extracts & 77.3 & 117 & 118 & 120 \\
$\quad$ neutral detergent & 29.5 & 31.8 & 19.6 & 29.8 \\
$\quad$ acid detergent & 19.55 & 19.22 & 19.43 & 18.94 \\
\hline
\end{tabular}

Table 3. Amino acid composition ( $\mathrm{g} \mathrm{kg}^{-1} \mathrm{DM}$ ) and amino acid profile (mg/16 $\mathrm{g} \mathrm{N}$ ) of hulless oat varicties

\begin{tabular}{|c|c|c|c|c|c|c|c|c|}
\hline \multirow[b]{2}{*}{$\begin{array}{l}\text { Amino } \\
\text { acid }\end{array}$} & \multicolumn{4}{|c|}{ Amino acid composition } & \multicolumn{4}{|c|}{ Amino acid profile } \\
\hline & Paul & $\begin{array}{c}\text { Gehl } \\
\text { VAO-02 }\end{array}$ & $\begin{array}{c}\text { AC } \\
\text { Gwen }\end{array}$ & $\begin{array}{c}\text { Lee } \\
\text { Williams }\end{array}$ & Paul & $\begin{array}{c}\text { Gehl } \\
\text { VA0-02 }\end{array}$ & $\begin{array}{c}\text { KC } \\
\text { Gwen }\end{array}$ & Lee Williams \\
\hline \multicolumn{9}{|c|}{ Indispensable } \\
\hline Arg & 13.1 & 12.3 & 11.0 & 10.5 & 71.2 & 71.93 & 68.32 & 68.83 \\
\hline His & 4.29 & 4.07 & 3.64 & 3.54 & 23.32 & 23.80 & 22.61 & 23.14 \\
\hline Ile & 7.51 & 7.07 & 6.10 & 6.01 & 40.82 & 41.35 & 37.89 & 39.28 \\
\hline Leu & 14.5 & 14.3 & 12.7 & 12.2 & 78.70 & 83.63 & 78.88 & 79.74 \\
\hline Lys & 7.94 & 7.93 & 7.60 & 7.08 & 43.15 & 46.37 & 47.20 & 46.27 \\
\hline Met & 3.22 & 3.22 & 3.32 & 3.00 & 17.50 & 18.83 & 20.62 & 19.61 \\
\hline Phe & 10.3 & 9.75 & 8.35 & 8.15 & 55.98 & 57.02 & 51.86 & 53.27 \\
\hline Thr & 6.22 & 6.11 & 5.78 & 5.47 & 33.80 & 35.73 & 35.90 & 35.75 \\
\hline Val & 10.1 & 9.75 & 8.67 & 8.37 & 54.89 & 57.02 & 53.85 & 54.71 \\
\hline \multicolumn{9}{|c|}{ Dispensable } \\
\hline Ala & 9.01 & 8.68 & 8.24 & 7.73 & 48.97 & 50.76 & 51.18 & 50.52 \\
\hline Asp & 15.6 & 14.7 & 13.6 & 12.9 & 84.78 & 84.78 & 85.96 & 84.31 \\
\hline Cys & 5.04 & 5.36 & 5.46 & 4.83 & 27.39 & 31.35 & 33.91 & 31.57 \\
\hline Glu & 37.1 & 36.1 & 32.4 & 31.1 & 201.6 & 211.1 & 201.2 & 203.3 \\
\hline Gly & 9.01 & 8.90 & 8.67 & 8.05 & 48.97 & 52.05 & 53.85 & 52.61 \\
\hline Pro & 9.23 & 8.57 & 8.46 & 8.05 & 50.16 & 50.12 & 52.55 & 52.61 \\
\hline Ser & 8.15 & 7.93 & 7.39 & 6.97 & 44.29 & 46.37 & 45.90 & 45.56 \\
\hline Tyr & 5.69 & 5.25 & 5.14 & 4.83 & 30.92 & 30.70 & 31.93 & 31.57 \\
\hline
\end{tabular}


varieties. The fat content $\left(\mathrm{g} \mathrm{kg}^{-1} \mathrm{DM}\right)$ in the hulless oat varieties ranged from 53.8 to 72.1 with an average of $64.6 \mathrm{~g} \mathrm{~kg}^{-1} \mathrm{DM}$, whereas the gross energy content ranged from 18.94 to 19.55 with an average of $19.3 \mathrm{MJ} \mathrm{kg}^{-1} \mathrm{DM}$. The NDF content in the hulless oat varieties ranged from 77.3 to 120 with an average of $108.1 \mathrm{~g} \mathrm{~kg}^{-1} \mathrm{DM}$, whereas the ADF content ranged from 19.6 to 31.8 with an average of $27.7 \mathrm{~g} \mathrm{~kg}^{-1} \mathrm{DM}$. The AA content, like CP content, were lowest for LW and highest for PA (Table 3). The AA profile (expressed in mg $16^{-1} \mathrm{~g} \mathrm{~N}$ ) was, however, comparable among the four oats varieties.

Apparent nutrient digestibility. The AID of DM, N and AA of the four oat varieties are presented in Table 4. The AID of DM was higher $(\mathrm{P}<0.05)$ in $\mathrm{AC}$ than in the other three varieties, which were in turn similar. The AID of $N$ for GV was the least and lower $(\mathrm{P}<0.05)$ than that for $\mathrm{AC}$ and $\mathrm{PA}$ varieties which were in turn similar $(\mathrm{P}>0.05)$. In general, $\mathrm{AC}$ had higher $(\mathrm{P}<0.05) \mathrm{AID}$ for all AA when compared with the other three varieties. The apparent ileal digestibility

Table 4. Apparent ileal digestibility of dry matter, energy, crude protein and amino acids of hulless oat varieties, $\%$

\begin{tabular}{|c|c|c|c|c|c|}
\hline \multirow[b]{2}{*}{ Item } & \multicolumn{4}{|c|}{ Hulless oat varieties } & \multirow[b]{2}{*}{ SEM } \\
\hline & Paul & $\begin{array}{c}\text { Gehl- } \\
\text { VAO-02 }\end{array}$ & AC Gwen & Lec William & \\
\hline$\overline{\text { Dry matter }}$ & $75.1^{\mathrm{b}}$ & $71.0^{\circ}$ & $82.1^{\mathrm{a}}$ & $73.4^{\mathrm{b}}$ & 1.51 \\
\hline Nitrogen & $73.0^{\mathrm{ab}}$ & $64.4^{\mathrm{bc}}$ & $78.5^{\mathrm{a}}$ & $62.2^{\mathrm{c}}$ & 2,62 \\
\hline Energy & $75.8^{\mathrm{b}}$ & $70.7^{\mathrm{b}}$ & $82.5^{\mathrm{a}}$ & $75.2^{b}$ & 1.57 \\
\hline \multicolumn{6}{|c|}{ Indispensable amino acids } \\
\hline Arg & $84.6^{\mathrm{b}}$ & $83.3^{\mathrm{b}}$ & $90.1^{\mathrm{a}}$ & $84.0^{\mathrm{b}}$ & 1.03 \\
\hline His & $78.9^{\mathrm{b}}$ & $76.8^{\mathrm{b}}$ & $86.7^{\mathrm{a}}$ & $77.3^{\mathrm{b}}$ & 1.69 \\
\hline Ile & $79.4^{\mathrm{b}}$ & $77.3^{\mathrm{b}}$ & $85.7^{\mathrm{a}}$ & $76.8^{b}$ & 1.58 \\
\hline Leu & $80.2^{b}$ & $78.2^{\mathrm{b}}$ & $87.3^{\mathrm{a}}$ & $78.3^{b}$ & 1.53 \\
\hline Lys & $67.1^{\mathrm{b}}$ & $65.7^{\mathrm{b}}$ & $78.9^{\mathrm{a}}$ & $60.0^{\mathrm{b}}$ & 2.53 \\
\hline Met & $81.1^{\mathrm{b}}$ & $80.7^{\mathrm{b}}$ & $89.6^{\mathrm{a}}$ & $82.6^{b}$ & 1.11 \\
\hline Phe & $83.7^{\mathrm{b}}$ & $81.9^{\mathrm{b}}$ & $89.2^{\mathrm{a}}$ & $82.1^{b}$ & 1.30 \\
\hline Thr & $62.9^{\mathrm{b}}$ & $59.1^{\mathrm{b}}$ & $75.8^{4}$ & $52.7^{\mathrm{b}}$ & 3.59 \\
\hline Val & $76.4^{\mathrm{b}}$ & $74.9^{b}$ & $84.9^{4}$ & $75.0^{\mathrm{b}}$ & 1.69 \\
\hline mean, indispensable & $77.1^{\mathrm{b}}$ & $75.3^{\mathrm{b}}$ & $85.3^{\mathrm{a}}$ & $74.3^{b}$ & 1.71 \\
\hline \multicolumn{6}{|l|}{ Dispensable amino acids } \\
\hline Ala & $69.7^{\mathrm{b}}$ & $65.1^{\mathrm{b}}$ & $79.8^{3}$ & $63.7^{\mathrm{b}}$ & 2.75 \\
\hline Asp & $73.8^{\mathrm{ab}}$ & $69.4^{\mathrm{b}}$ & $81.6^{\mathrm{a}}$ & $67.7^{\mathrm{b}}$ & 2.26 \\
\hline Cys & $67.1^{\mathrm{ab}}$ & $58.5^{\mathrm{b}}$ & $77.9^{\mathrm{a}}$ & $58.5^{\mathrm{b}}$ & 3.52 \\
\hline Glu & $85.6^{\mathrm{b}}$ & $84.1^{\mathrm{b}}$ & $90.9^{\mathrm{a}}$ & $84.4^{\mathrm{b}}$ & 1.02 \\
\hline Gly & $61.1^{\mathrm{ab}}$ & $51.9^{\mathrm{h}}$ & $72.5^{\mathrm{a}}$ & $52.3^{\mathrm{b}}$ & 4.09 \\
\hline Pro & $74.8^{\mathrm{ab}}$ & $69.0^{\mathrm{bc}}$ & $82.6^{\mathrm{a}}-\mathrm{r}-\mathrm{r}-\mathrm{a}$ & $61.8^{\mathrm{c}}$ & 2.78 \\
\hline Ser & $69.3^{b}$ & $62.7^{\mathrm{b}}$ & $78.8^{\mathrm{s}}$ & $59.9^{\mathrm{b}}$ & 2.58 \\
\hline Tyr & $73.6^{\mathrm{b}}$ & $68.8^{\mathrm{b}}$ & $81.2^{\mathrm{s}}$ & $66.7^{\mathrm{b}}$ & 2.11 \\
\hline mean, dispensable & $71.9^{\mathrm{b}}$ & $66.2^{\mathrm{b}}$ & $80.6^{\mathrm{a}}$ & $64.4^{\mathrm{b}}$ & 2.49 \\
\hline Mcan, total amino acids & $74.5^{\mathrm{b}}$ & $70.7^{\mathrm{b}}$ & $83.0^{\mathrm{a}}$ & $69.3^{\mathrm{b}}$ & 2.04 \\
\hline
\end{tabular}


values for $\mathrm{PA}, \mathrm{GV}$, and $\mathrm{LW}$ were not significantly different $(\mathrm{P}<0.05)$. Among the indispensable AA, the apparent ileal digestibility values for threonine were the lowest followed by those for lysine in all four hulless oat cultivars evaluated. Arginine had the highest AID in all varieties of all the indispensable AA. For dispensable AA, glutamic acid had the highest AID and glycine the least among the hulless oat varieties. The digestibility of energy at the ileal level was higher $(\mathrm{P}<0.05)$ for $\mathrm{AC}$ compared with the other three oat varieties whose values were similar (Table 4).

Table 5. Apparent total tract digestibilities of dry matter, crude protein and gross energy, and digestible and metabolizable energy content in hulless oats fed to growing pigs $(n=4)$

\begin{tabular}{|c|c|c|c|c|c|}
\hline \multirow{2}{*}{ Item } & \multicolumn{4}{|c|}{ Hulless oat varieties } & \multirow{2}{*}{ SEM } \\
\hline & Paul & Gehl VAO-02 & $\mathrm{AC}$ Gwen & Lee Williams & \\
\hline \multicolumn{6}{|l|}{ Digestibility, \% } \\
\hline dry matter & $94.5^{\mathrm{a}}$ & $93.6^{\mathrm{a}}$ & $93.3^{\mathrm{a}}$ & $90.4^{b}$ & 0.49 \\
\hline crude protein & $95.8^{\mathrm{a}}$ & $94.0^{\mathrm{ab}}$ & $95.5^{\mathrm{a}}$ & $92.9^{b}$ & 0.54 \\
\hline gross energy & $94.8^{\mathrm{a}}$ & $93.9^{\mathrm{a}}$ & $93.7^{\mathrm{a}}$ & $91.0^{b}$ & 0.46 \\
\hline \multicolumn{6}{|c|}{ Energy content, $M J \mathrm{~kg}^{-1} \mathrm{DM}$} \\
\hline digestible & $17.92^{\mathrm{a}}$ & $17.44^{\mathrm{b}}$ & $17.61^{\mathrm{bb}}$ & $16.66^{\mathrm{c}}$ & 0.080 \\
\hline metabolizable & $17.90^{\mathrm{a}}$ & $17.43^{\mathrm{b}}$ & $17.58^{\text {ub }}$ & $16.65^{\circ}$ & 0.081 \\
\hline
\end{tabular}

Table 5 shows the apparent total tract digestibility (ATTD) of DM, N and energy and the DE and ME content in the hulless oat varieties evaluated. The ATTD of DM and N was lower $(\mathrm{P}<0.05)$ in $\mathrm{LW}$ than in PA and AC; the value for $\mathrm{GV}$ was intermediate. Hulless oat varieties PA, GV, and AC had similar ATTD of energy values and were higher $(\mathrm{P}<0.05)$ than the value observed for $\mathrm{LW}$. The $\mathrm{DE}$ and $\mathrm{ME}$ values for $\mathrm{PA}$ were similar $(\mathrm{P}>0.05)$ to those of $\mathrm{AC}$ Gwen but higher $(\mathrm{P}<0.05)$ than those for GV and LW.

\section{DISCUSSION}

The CP values for the hulles oat varieties tested in the current study are slightly lower than the value reported by NRC (1998) for naked oat, but higher than values reported for other naked oat varieties (Brand and van der Merwe, 1996; Givens et al., 2004). The hulless oat varieties evaluated had fat content values that are comparable to those reported in the literature (NRC, 1998; Thacker et al., 2004) and are higher than those for conventional oats $\left(52.8 \mathrm{~g} \mathrm{~kg}^{-1} \mathrm{DM}\right)$, barley $(21.3 \mathrm{~g}$ $\mathrm{kg}^{-1} \mathrm{DM}$ ), maize (43.8 $\mathrm{g} \mathrm{kg}^{-1} \mathrm{DM}$ ) and wheat (22.7 $\left.\mathrm{g} \mathrm{kg}^{-1} \mathrm{DM}\right)(\mathrm{NRC}, 1998)$. As fat contains very high energy content, hulless oat may be a good source of energy for 
pig. The fibre (ADF and NDF) contents in the four oat varieties were very similar to those reported for naked oat (NRC, 1998) and were lower than for conventional oats (NRC, 1998). Studies have shown that high dietary fibre reduces feed intake and nutrient utilization in pigs (e.g., Noblet and Le-Goff, 2001). Thus, with lower fibre content, it can be expected that hulless oat could be used in larger amounts as a feedstuff for pig, particularly young pig.

In general, all oat varieties had higher AA content compared to cereals commonly used in pig diets. For example, the content $\left(\mathrm{g} \mathrm{kg}^{-1} \mathrm{DM}\right)$ of lysine in hulless oat averaged 7.64, which is considerably higher than values (on DM basis) reported for conventional oat (4.5), maize (2.9), wheat (3.9) and barley (4.6) (NRC, 1998). The hulless oats evaluated in the current study had higher AA content than the cultivar evaluated by Thacker (2006); a difference that may be explained in part by the differences in the $\mathrm{CP}$ contents of the varieties evaluated in the two studies.

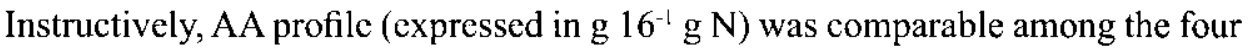
oats varieties. These observations agree with those of Van Barneveld et al. (1998) and Givens et al. (2004) who reported similar AA profiles among the hulless oat varieties when expressed as proportion of the $\mathrm{N}$ content.

Based on the analysed CP levels of the four oats varieties (Table 2), the CP contents ( $\mathrm{g} \mathrm{kg}^{-1}$, as fed) of the four diets used in the present study were: 165,154 , 149 and 138 for PA, GV, AC and LW, respectively. Sauer et al. (1980) suggested that apparent ileal digestibilities (AID) values of AA should only be compared under standardized conditions with dietary CP contents of at least $150 \mathrm{~g} \mathrm{~kg}^{-1}$, yet Van Barneveld et al. (1994) showed that little difference was observed in the AID of AA in diets with CP levels above $105 \mathrm{~g} \mathrm{~kg}^{-1}$, a level exceed by all diets in the present study. However, as $\mathrm{CP}$ content was not equalized among the diets, differing proportions of endogenous $\mathrm{N}$ contributions may have influenced the AID of AA reported in the present study (Nyachoti et al., 1997). The AID of DM in the hulless oats evaluated in the present study were comparable to the values reported for growing pigs by Van Barneveld et al. (1998). Overall, the average AID of $\mathrm{N}$ was $70 \%$ and was lower than AID of N (79\%) for two Australian hulless oat varieties fed to growing pigs ( $38 \mathrm{~kg}$ body weight) as reported by Van Barneveld et al. (1998). In pig, body weight and dietary CP contents are the most important among the factors that influence ileal $\mathrm{N}$ digestibility (Nyachoti et al., 1997). Since older pigs and diets with high CP contents are expected to have higher AID of N, these two factors does not explain the differences between AID of $\mathrm{N}$ observed for the present study (diet CP range of $138-165 \mathrm{~g} \mathrm{~kg}^{-1}$ ) and that of Van Barneveld et al. (1998) (diet CP ranged from 102-149 $\mathrm{g} \mathrm{kg}^{-1}$ ). Rather, the differences are likely duc to the indigestible markers used in the two studies. Chromic oxide was used in the present study whereas acid insoluble ash (celite) was used in Van Barneveld et al. (1998) study and differences in recovery might have influenced the results 
as discussed elsewhere (Stein et al., 2007).

To our knowledge, the apparent ileal digestibility of AA for hulless oat has only been determined in one study (Van Barneveld et al., 1998) and consequently such data are lacking in the NRC (1998) publication. It is well accepted that for accurate diet formulation with respect with AA supply, ileal digestibility values should be used (Stein et al., 2007) and therefore it is critical that such values are determined. The AID of AA for the AC were higher than values for maize, barley and wheat as reported by the NRC (1998), whereas AID of AA for the PA, GV and LW were generally comparable to values reported for maize, barley, wheat and hulled oat (NRC, 1998). Lysine is often the first limiting AA in pig diets and therefore nutritionists pay particular attention to this AA when formulating pig diets. The apparent ileal digestibility of lysine varied from a low of $60.0 \%$ for LW to a high of $78.9 \%$ for $\mathrm{AC}$, with an overall average value of $67.9 \%$ for all four varieties. Corresponding values for cereal grains commonly used in pig diets are $68 \%$ for barley, $66 \%$ for maize, and $73 \%$ for wheat (NRC, 1998). Compared with the AID values for AA reported by Van Barneveld et al. (1998) for hulless oat fed to growing pigs, only $\mathrm{AC}$ had comparable values for most $\mathrm{AA}$ in the present study whilst the AID of AA in the other three hulless oats were considerably lower. Specifically, the AID of lysine and threonine in PA, GV, and LW averaged 64.3 and $58.2 \%$, respectively, which are substantially lower than the values of 85.5 and $77.5 \%$, respectively, reported by Van Barneveld et al. (1998). It is noteworthy, however that, the contents ( $\mathrm{g} \mathrm{kg}^{-1} \mathrm{DM}$ ) of lysine (6.1) and threonine (5.2) of the two hulless oats used in Van Barneveld et al. (1998) study were much lower than those of the four oats ( 7.7 and $5.9 \mathrm{~g} \mathrm{~kg}^{-1} \mathrm{DM}$ for lysine and threonine, respectively) used in the present study. In this context, it is likely that the choice of a marker might have influenced the AID of AA as previously discussed for AID of N. Future evaluation of AID of AA in hulless oats should resolve this issuc by determining comparative recovery rates of different markers in ileal digesta from pigs.

Except for GV whose AID value of $70.7 \%$ was considerably lower, the values observed for the other three varieties were comparable to those reported by Van Barneveld et al. (1998) for naked oat cultivar Bandicoot. The average ATTD of DM $(93 \%)$ for the four hulless oats was higher than 88 and $86.6 \%$ reported for growing pigs by Van Barneveld et al. (1998) and Brand and Van der Merwe (1996), respectively. Averaged among the four hulless cultivars, the ATTD of energy of $93.4 \%$ was comparable to a value of $90 \%$ reported by Van Barneveld et al. (1998) but higher than $86.6,75.4$ and $74.3 \%$ reported for naked oats by Brand and Van der Merwe (1996), Thacker et al. (2004) and Thacker (2006), respectively. As mentioned above, the cultivars evaluated in the current study had higher fat content than the cultivars evaluated in the studies of Thacker et al. (2004) and Thacker (2006), a factor that is likely responsible for the differences 
seen in total tract energy digestibility among these studies. Whereas, immature digestive system of young pigs ( $26 \mathrm{~kg}$ body weight) in Brand and Van der Merwe (1996) study may have resulted to lower ATTD of energy.

The mean DE value for the four hulless oats in the present study was $17.41 \mathrm{MJ}$ $\mathrm{kg}^{-1} \mathrm{DM}$. This is in good agreement with estimates of $17.9 \mathrm{MJ} \mathrm{kg}^{-1}$ determined previously with growing pigs (Brand and Van der Merwe, 1996). However, it is higher than estimates of 16.36 and $16.20 \mathrm{MJ} \mathrm{kg}^{-1} \mathrm{DM}$ reported by NRC (1998) and Muley et al. (2005), respectively, and lower than estimates of 18.84 and 18.05 MJ kg-1 DM reported by Van Barneveld et al. (1998) and Givens et al. (2004), respectively. Perhaps such differences in reported DE values are due to varietal and growing environmental conditions as previously reported for hulless oats (Givens et al., 2004). Overall, the four varieties of oat had, however, higher DE values than those reported by Muley et al. (2005) for hulless barley (14.87 MJ $\mathrm{kg}^{-1}$ ) and by Opapeju et al. (2007) for several Manitoba-grown maize cultivars, which ranged from 15.17 to $15.40 \mathrm{MJ} \mathrm{kg}^{-1} \mathrm{DM}$. The ME values of the four hulless oats reported in the present study were higher than estimate of $16.6 \mathrm{MJ} \mathrm{kg}^{-1} \mathrm{DM}$ reported by NRC (1998).

\section{CONCLUSIONS}

The results show that hulless oat varicties (i.e. Paul, Gehl-VAO-02, AC Gwen and Lee Williams) had higher energy and amino acid content than most other ccreals commonly used in pig diets. The digestibilities of protein and amino acids were generally comparable to the values reported for other cereal except for AC Gwen, whose values were considerably higher. The higher digestible and metabolizable energy content of the hulless oat varieties tested makes them excellent energy sources for pig diets compared to traditionally used cereal grains such as maize and barley. Similarly, the higher amino acid content in the oats tested implies that these feedstuffs could also be viewed as an important source of dietary amino acids in pig diets.

\section{ACKNOWLEDGMENTS}

We gratefully acknowledge Manitoba Oat Growers Association for funding the project and providing hulless oats samples. 


\section{REFERENCES}

AOAC, 1990. Association of Official Analytical Chemists, Official Methods of Analysis. $15^{\text {th }}$ Edition. Washington, DC

Brand J.S., van der Merwe J.P., 1996. Naked oats (Avena nuda) as a substitute for maize in diets for weanling and grower-finishing pigs. Anim. Fecd Sci. Tech. 57, 139-147

Canadian Council on Animal Care (CCAC), 1993. Guide to the Care and Use of Experimental Animals. 2nd Edition. Vol.l. CCAC. Ottawa, ON

Givens D.I., Davies T.W., Laverick R.M., 2004. Effect of variety, nitrogen and various agronomic factors on the nutritive value of husked and naked oats grain. Anim. Feed Sci. Tech. 113, 169181

Morris J.R., 1990. Oats: Naked. In: P.A. Thacker, R.N. Kirkwood (Editors). Nontraditional Fecd Sources for Use in Swine Production. Butterworths, London, pp. 275-284

Muley N., van Heugten E., Zhang W., Harris E., van Kempen T., 2005. Comparison of nutritional value and ammonia emission in hulless barley, naked oats, and corn for growing pigs. In: G.B. Havenstein (Editor). Animal Waste Management Symposium. College of Agriculture and Life Sciences, North Carolina State University, NC

Noblet J., Le-Goff G., 2001. Effect of dietary fibre on the energy value of feeds for pigs. Anim. Feed Sci. Tech. 90, 35-52

NRC, 1998. Nutrient Requirements of Swine. 10th Edition. National Research Council, National Academic Press. Washington, DC

Nyachoti C.M., Arntfield S.D., Guenter W., Cenkowski S., Opapeju F.O., 2006. Effect of micronized pea and enzyme supplementation on nutrient utilization and manure output in growing pigs. J. Anim. Sci. 84, $2150-2156$

Nyachoti C.M., de Lange C.F.M., McBride B.W., Schulze H., 1997. Significance of endogenous gut protein losses in the nutrition of growing pigs: A review. Can. J. Anim. Sci. 77, 149-163

Nyachoti C.M., McNeilage-Van de Wiele E.M., de Lange C.F.M., Gabert V.M., 2002. Evaluation of the homoarginine technique for measuring true ileal amino acid digestibilities in pigs fed a barley-canola meal-based diet. J. Anim. Sci. 80, 440-448

Opapeju F.O., Nyachoti C.M., House J.D., 2007. Digestible energy, protein and amino acid content in selected shorted season corn cultivars fed to growing pigs. Can. J. Anim. Sci. 87, 221-226

Sauer W.C., Just A., Jorgensen H.H., Fekadu M., Egum B.O., 1980. The influence of diet composition on the apparent digestibility of crude protein and amino acids at the terminal ileum and overall in pigs. Acta Agr. Sand. 30, 449-457

Stein H.H., Sève B., Fuller M.F., Moughan P.J., de Lange C.F.M., 2007. Invited review: Amino acid bioavailability and digestibility in pig feed ingredients: Terminology and application. J. Anim. Sci. $85,172-180$

Thacker P.A., 2006. Performance of growing-finishing pigs fed diets containing normal or low lignin-high fat oat processed using a hammer mill or roller mill. J. Anim. Vet. Adv. 5, 662-669

Thacker P.A., Soita H.W., Rossnagel B., 2004. Performance of growing-finishing pigs fed barleybased diets supplemented with normal or high-fat oat. Can. J. Anim. Sci. 84, 229-236

Van Barneveld R.J., Batterham E.S., Norton B.W., 1994. The effect of heat on amino acids for growing pigs. I. A comparison of apparent ileal and fecal digestibilities of amino acids in raw and heat-treated filed peas. Brit. J. Nutr. 72, 221-241

Van Barneveld R.J., Szarvas S.R., Barr A.R., 1998. The apparent ileal digestibility of amino acids and the digestible energy content of naked oats (Aven sativa cv Bamdicoot) fed to growing pigs. J. Sci. Food Agr. 76, 277-284 
Van Soest P.J., Robertson J.B., Lewis B.A., 1991. Methods for dietary fiber, neutral detergent fibre, and non-starch polysaccharides in relation to animal nutrition. J. Dairy Sci. 74, 3583-3597

Williams C.H., David D.J., Iismaa O., 1962. The determination of chromic oxide in fecal samples by atomic absorption spectrophotometry. J. Agr. Sci. 59, 381-385 